\title{
Political Environment and Biosocial Projects Performance in Informal Settlements in Nairobi County, Kenya
}

\author{
Ngacha Njeri ${ }^{1}$, Christopher Mwangi Gakuu ${ }^{2} \&$ Kidombo Harriet Jepchumba ${ }^{3}$ \\ ${ }^{1}$ Department of Open Distance and e-Learning, University of Nairobi, Kenya \\ ${ }^{2}$ Director School of Open Distance and e-Learning, University of Nairobi, Kenya \\ ${ }^{3}$ Deputy Director School of Continuing and Distance Education, University of Nairobi, Kenya \\ Correspondence: Ngacha Njeri, Department of Open Distance and e-Learning, University of Nairobi, Kenya. Tel: \\ 254-7-2039-3738. E-mail: snnjeri@gmail.com
}

Received: November 28, 2020

Accepted: March 7, $2021 \quad$ Online Published: March 9, 2021

doi:10.5539/jsd.v14n2p111

URL: https://doi.org/10.5539/jsd.v14n2p111

\begin{abstract}
This research study strived to find out the influence of Political Environment on biosocial projects performance in informal settlements in the county of Nairobi. The extent to which political environment influence biosocial project performance. Biosocial projects are projects working with people with disabilities. Two theories, Theory of Constraint and diffusion were used in this field of study to support predictive and outcome variable respectively. Pragmatism paradigm and mixed research were adopted in this study projects. Quantitative data was collected through structured self-administered questionnaires while qualitative data was collected through interview guides. Collection of data was preceded by testing for validity of research instruments through reliability and content related method through test-retest criterion. In Nairobi County, a sample size of 183 individuals from 61 biosocial projects were selected from a target sample of 70 biosocial projects. Questionnaires were used to collect quantitative data from 61 beneficiaries of the biosocial projects and 61 staff members directly working for biosocial projects in the County of Nairobi. In- depth qualitative interviews with 61 state and non-state actors through purposive sampling technique were executed. Arithmetic mean and the standard deviation were the statistical tools of analysis that were used for descriptive data, whereas Stepwise Regression $\left(\mathrm{R}^{2}\right)$ and Pearson's Product Moment Correlation (r) were the statistical tools of analysis that were used for inferential statistics whereas F-tests were executed to test hypothesis. To avoid statistical analysis invalidation, statistical assumptions tests were executed before analysis of data. Null hypothesis after analysis of data analysis was rejected at $r=0.313, F=8.988, p=$ $0.004<0.01$. Conclusively, constitution of Kenya 2010 and the Persons with Disabilities Act, 2003 were some of the key legal legislation that were pointed out to be championing success of biosocial projects performance that champion for the rights of persons with disabilities.
\end{abstract}

Keywords: political environment, power relations, projects performance, organizational politics, politics of identity, informal settlements

\section{Introduction}

Movements of individuals from upcountry to town areas has been found to be the most critical variable contributing to the population growth within Nairobi County in Kenya. Most people move to Nairobi which is the capital city of the Kenyan republic from different parts of the country looking for employment opportunities. A significant number of the individuals migrating to Nairobi only manage to reside in informal settlement, a factor which promotes mushrooming of informal settlements, (NCIDP, 2014). As an outcome of expanded population, there exist a high pressure exerted on the available physical facilities and social amenities at large among the low and middle income earners.

The problems in the existing human settlement formations in the Nairobi sub-counties comprises of: pollution of the surroundings caused majorly by solid and liquid waste, inadequacy of land for public utilities as well as growth in the number of squatters, (NCIDP, 2014). The expansion in population does not move in line with increase in infrastructure thus exerting pressure on the little reserve that is available. This therefore promotes a high need for improvement in sanitation mainly to bring down the likelihood of contracting disease.

Moreover, the local authority has been incapable of providing effective as well as efficient services of health to 
the residents as a result of limited resources to put into building facilities of health, upgrading in addition to modernizing the already in place. Thus, provision of enough health and social amenities should be prioritized since this will ensure reality of existence of a healthy populace.

\subsection{Statement of the Problem}

Projects viewed to be highly influenced by politics naturally are also considered not to be impartial as well as being less honorable. Politics in the organizations have been contributed by impartiality and self insterest by the leadership, (Vigoda 2002). However, increased radical degrees in organizations on most occasions shows the evidence of in equitable circulation of resources and injustice between employees, (Dekings,2015). Such circumstances are likely to promote increased stress level as well as strain; weakened employee performance, reduced commitment to the organization, low-slung levels of job fulfillment and additional destructive responses.

After the commencement of a project, the objectives should remain intact and not changeable since the alteration of intended achievements is affected if objectives are changed thus may cause contradiction as to whether a new undertaking has been initiated. Modifying objectives may however take place in small steps well known as scope creep age besides they are not comprehended to partake a far reaching influence. A sum up of these little modifications, if not well monitored, may alter the target of the project by a large magnitude. The manager in command of the project compares all courses of actions with regards to the modifications made with respect to singular intentions to ensure that it does not take place.

External communication and relationships, reliable systems of communication as well as clarity of staff posts, commitment and energy of staff are enabling factors identified in many successfully implemented projects, (Saxon, 2011). Equally, stakeholder's feedback in relation to staff passion, communication and positive relationships between the same staff groups are implicated in organizational efficiency, (Gray et al; 2011). According to Willey (2007), organizational culture is critical to operational project performance since existence of good governance structures presents a competitive advantage to projects performance as equally in case of introducing a new software or other communication strategies.

\subsection{Study Objectives}

To establish the extent to which political environment influence of biosocial projects performance in informal settlements in Nairobi County, Kenya.

\subsection{Study Hypothesis}

The study tested the following null hypothesis:

Ho: There is no significant influence of political environment on biosocial projects performance.

\section{Literature Review}

Presumably, one of the noted risks of public participation initiatives is lack of genuineness from top management in decision making for fear of politicizing or questioning of the projects affairs during the running of projects. Political environment of a project according to Neshkova and Guo (2011) is the relationship that exists between elected leaders and non-elected officials including government officers and public ran projects. As espoused by Neshkova Guo (2011), environmental variables influencing a project can be categorized as political variables, legal variables, institutional variables, cultural variables, sociological variables, technological variables as well as economic and physical infrastructure variables.

Engaging public in the administration of project is perceived central and crucial where a large number of participants are taking part from distinct profession but merge together to make a choice to benefit every individual in the project (Brenda, 2001). Metzger et al., (2012), has however a contradicting opinion where view on involvement of the public in the management of a project that hold that many professionals may be brought on board from NGOs, Agencies of government, volunteers and key community gate keepers in addition to opinion leaders. This is so as to neutralize leadership tensions and pressures attributed with personal issues and wrong judgements that may cause stagnation in any project progress.

There exists quite a number of frameworks in which illustrations regarding the administration systems of politics which occur frequently (Sobel, 1993). This can be shown for example where public projects as they are naturally designed they are heavily associated with politics and engrossed in the government systems of running affairs. In the studies by Peterson (1990), a spillover effect has been identified to be linked to skills in politics, attitudes.

\subsection{Theoretical Framework}

Studies are premised on exceptional theory, thus this study was supported by diffusion theory and theory of 
constraint. The two theories supported predictive variable political environment and outcome theory of biosocial projects performance in informal settlements in Nairobi County Kenya respectively (Singleton 1998).

\subsubsection{Theory of Diffusion}

Theory of diffusion was propounded by E.M Rogers in 1962.The idea of the theory was to explain how ideas gets and accepted into communities by way of diffusion. In this study theory of diffusion will be key to provide critical knowledge on predictive variable political environment. The theory's concept of compatibility is attributed by observability, innovation, complexity, relative advantage besides trialability (Rogers 2003). Theory of diffusion has remained widely applied in performance science as per Vollink et al, (2002).

\subsubsection{Theory of Constraints}

The theory is mainly applied in the management of projects so as to facilitate approach to the critical matters which may cause project delays or failures (Pittman, 1994), thus this is the major reason for it to be considered a reinforcing support of projects performance.

\subsection{Study Conceptual Framework}

For this study Conceptual Framework focused on two prime variables as per the figure 1 below:

\section{Dependent Variable}

\section{Independent Variable}

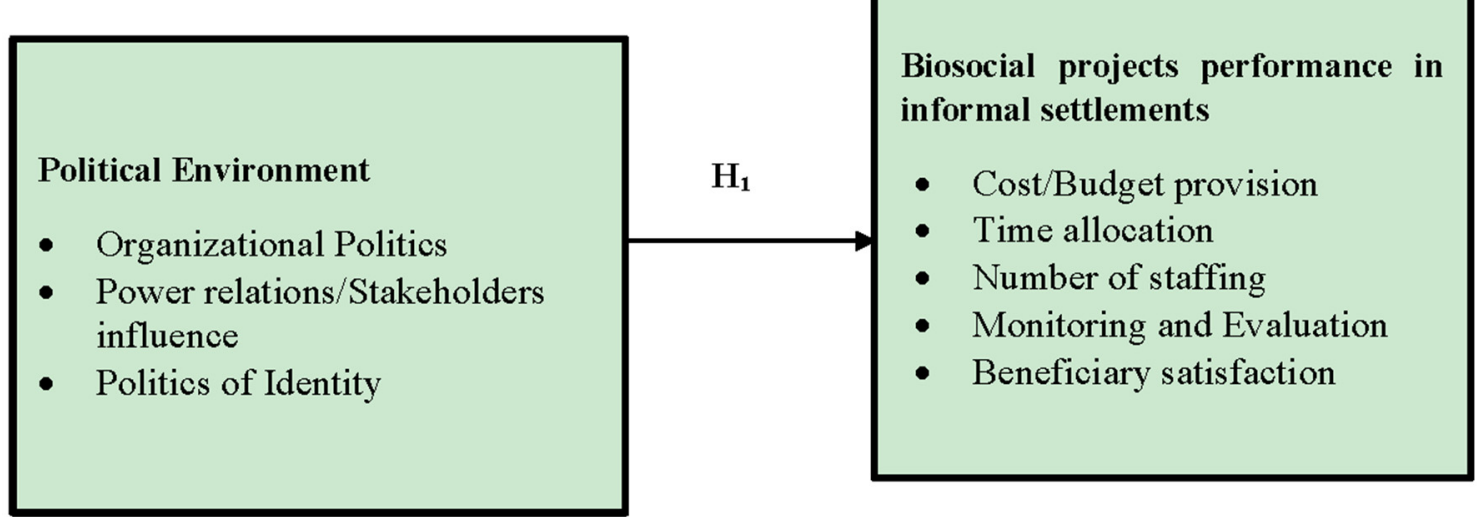

Figure 1. Political environment and biosocial projects performance conceptual framework

\section{Research Methodology}

This research study was guided by pragmatism paradigm considering that it used mixed method of data collection and analysis since in addition pragmatism paradigm accommodates both the constructivist and positivist philosophies. Subsequently, the research design that was expended in this study was correlational research design and descriptive survey design. Sixty-one (61) projects for biosocial community was the sample size for this research study. Qualitative data was collected though an interview guide that was administered to Key informants.

\section{Findings and Discussions}

In this research study correlational research and descriptive research designs approach were expended. Where else descriptive, inferential analysis in addition to qualitative statistical examination were conducted simultaneously. Descriptive analysis in support of the research objective was executed foremost through testing mean as well as the standard deviation then trailed by application of Person's Product Moment Correlation for execution of inferential analysis.

\subsection{Respondents Background Information}

122 questionnaires were dispensed and out of it 117 were fully answered, while 5 were incomplete in some instances; $95.9 \%$ response rate was worthy for the study inferences.

Gender of the respondents is as shown in Table 1 
Table1. Gender of the respondents

\begin{tabular}{lcc}
\hline Gender & Frequency & $\begin{array}{c}\text { Percentages } \\
\text { (\%) }\end{array}$ \\
\hline Male & 32 & 27.4 \\
Female & 85 & 72.6 \\
\hline Total & 117 & 100.0 \\
\hline
\end{tabular}

4.1.1 Distribution of Respondents by Age

Classification of age was depicted as per the following table 2 .

Table 2. Age of respondents

\begin{tabular}{ccc}
\hline Age & Frequency & Percentage \\
\hline $20-30$ & 18 & $15 \%$ \\
$30-40$ & 33 & $27 \%$ \\
$40-50$ & 22 & $18 \%$ \\
$50-60$ & 5 & $4 \%$ \\
Above 60 & 1 & $1 \%$ \\
Age not reported & 43 & $35 \%$ \\
\hline Total & 122 & $100 \%$ \\
\hline
\end{tabular}

\subsubsection{Statistical Assumptions Tests and Likert Type of Data Analysis}

The importance of these tests is to check suitability and distribution and of data for a researcher to make inferences. Expended tests for this research study are: Multi collinearity Test, Test for Normality, Test for Singularity and Heteroscedasticity and Homoscedasticity tests. Likert scale suitability in the study was in extension attained and discussed by checking on Type 1 and Type 2 errors.

\subsubsection{Normality Test}

Regression testing undertakes that data collected is from a normal population. If the data is not from the normal population then it should be rejected (Moriya 2008). The null hypothesis is rejected if $\mathrm{p}<0.05$. as per Kolmogorov Shapiro -test. In all the variables $p<0.05$ which led to rejection of null hypothesis and conclusion made that the samples were selected from a normal population. Shapiro-Wilk tests (SW-test) were executed out to counter check validity of test of normality from KS-test statistic, P value in SW -test is denoted as Sig. And is enshrined in the last column. According to Shapiro and Wilk (1965) Kolmogorov-Smirnov test statistic establish whether a pair of datasets significantly vary without making any assumption about the distribution of data (Shapiro and Wilk 1965). The outcome is as shown in the table 3 underneath:

Table 3. Normality tests results of Shapiro-Wilk and Kolmogorov-Smirnova

\section{Statements}

\section{Normality Tests}

\begin{tabular}{|c|c|c|c|c|c|c|c|}
\hline & & Statistic & df & Sig. & Statistic & df & Sig. \\
\hline a) & Political environment & .078 & 64 & $.200^{*}$ & .985 & 64 & .603 \\
\hline b) & Biosocial projects performance in & .105 & 64 & .075 & .977 & 64 & .290 \\
\hline
\end{tabular}

*. This is a lower bound of the true significance.

a. Lilliefors Significance Correction 


\subsubsection{Multicollinearity and Singularity Test}

To make sure that the assumption is not violated Multicollinearity was tested by investigating tolerance values under collinearity (Asteriou and Hall, 2011). According to Shirley et al., (2005), 1 - R2 values ought to be more than 0.1 multicollinearity which is low. Singularity is said to be there if two variables are completely collinear and a precise linear association occurs amid two independent variables with a correlation coefficient equivalent to 1.0 or -1.0. The Predictor variable had a Variance Inflation Factor of less than 10, and the mean Variance Inflation Factor of 2.32 was less than 4 an impression that variables lacked a linear association amongst themselves, this then implies that there was no multicollinearity. The outcome of results is as shown in Table 4 below:

Table 4. Results of variance inflation factor (VIF)

\begin{tabular}{lcc}
\hline Independent Variables & \multicolumn{2}{c}{ Collinearity Statistics } \\
& Tolerance & VIF \\
\hline Political environment & .564 & 1.774 \\
Mean & & $\mathbf{2 . 0}$ \\
\hline Dependent Variable: Biosocial projects performance in informal settlements in Nairobi County & \\
\hline
\end{tabular}

\subsubsection{Tests for Heteroscedasticity and Homoscedasticity-Levene's Test}

Homoscedasticity was checked in this research study by checking at scatterplots between each independent variable and the outcome variable. This was done to ascertain that the cluster of points was nearly the similar width in the residuals plots stemmed from Scientific Package for Social Sciences program. Heteroscedastic is said to be there if there are sub-populations that have different inconsistencies from others). In Spherical-Homoscedastic distributions, Hamsici and Aleix (2007), claim that the correlation and residual tables generated by Scientific Package for Social Sciences to test for collinearity may as well be executed to inspect for presence of heteroscedasticity. This assumption in this study, was not violated.

Table 5 below lays down the test of homogeneity of variances

Table 5. Test of homogeneity of variances

\begin{tabular}{lcccc}
\hline Independent Variables & Levene Statistic & df1 & df2 & P-value \\
\hline Political environment & 2.228 & 20 & 46 & .130 \\
\hline
\end{tabular}

The factor in testing homogeneity is the independent variable, while the variable is the predictor variable. The pvalue is more than 0.05 implies the variables have met the assumption of homogeneity of variance that states there is equal variance across the range of the study variables.

\subsubsection{Control of Type I and Type II Errors}

In this research study analysis, low reliability was operated and got a composite Cronbach alpha of 0.944 and this warranted attaining a true depiction of the relationship of the variables and thus lowering the possibility of overestimation in the course of multiple regressions.

\subsubsection{Analysis of Likert Type Data}

The study had three main variables to test; the variables had sub-variables which had statements on a Likert scale of 1 to 1 points. The scale ranged from 5=Strongly Agree (SA), $4=$ Agree (AG), $3=$ Neutral (NE), $2=$ Disagree (DS), 1 = Strongly Disagree (SD). As recommended by Alan (2001) in the self-administered questionnaire in this study, the questionnaire sections comprised of items in a Likert type scale format using a scale of SD - Strongly Disagree; D - Disagree; N - Neutral; A - Agree; and SA - Strongly Agree.

\subsection{Overall Descriptive Analysis on Political Environment}

Table 6 below depicts mean, standard deviation and sample size of respondents to each aspect of each indicator: 
Table 6. Mean and standard deviation of political environment

\begin{tabular}{cccc}
\hline Political environment & $\mathbf{n}$ & Mean (M) & Standard Deviation \\
\hline Organizational politics & 122 & 3.85 & 1.15 \\
Power relations & 122 & 3.52 & 1.138 \\
Politics of identity & 122 & 3.21 & 1.25 \\
\hline Composite mean & $\mathbf{3 . 5 3}$ \\
\hline
\end{tabular}

The composite mean of 3.53 was approximately 4 , an indicator that on average the respondents agreed to most of the statements forming political environment. Each of the indicators forming political environment was further explored to check distribution of responses, results are discussed in preceding sub-sections.

4.3 Correlation between Political Environment and Biosocial Projects Performance in Informal Settlement Schemes

The results of the correlation to establish the direction and magnitude of the relationship between Political environment and biosocial projects performance. Are shown on table 7 below:

Table 7. Correlations among variables

\begin{tabular}{llllll}
\hline & & $\begin{array}{l}\text { Projects } \\
\text { Performance }\end{array}$ & $\begin{array}{l}\text { Legal } \\
\text { framework }\end{array}$ & Normative action & $\begin{array}{l}\text { Political } \\
\text { environment }\end{array}$ \\
\hline $\begin{array}{l}\text { Projects } \\
\text { performance }\end{array}$ & Correlation & $\mathbf{1}$ & $.382^{* *}$ & $.566^{* *}$ & $.313^{* *}$ \\
\hline & $\begin{array}{l}\text { Sig. (2-tailed) } \\
\text { N }\end{array}$ & 106 & 0.000 & 0.000 & 0.004 \\
& Correlation & $0.313^{* *}$ & $0.567^{* *}$ & $0.599^{* *}$ & $\mathbf{1}$ \\
\hline $\begin{array}{l}\text { Political } \\
\text { environment }\end{array}$ & Sig. (2-tailed) & $\begin{array}{l}0.004 \\
85\end{array}$ & $\begin{array}{l}0.000 \\
80\end{array}$ & $\begin{array}{l}0.000 \\
77\end{array}$ \\
\hline & $\mathbf{N}$ & & & 94 \\
\hline
\end{tabular}

Results above show that, political environment held a weak but positive correlation with projects performance. Importantly, the correlation held that they were all statistically significant.

Table 8 below present the results of the correlation:

Table 8. Correlation between political environment and biosocial projects performance in informal settlements

\begin{tabular}{lcccc}
\hline & & $\begin{array}{c}\text { Organizational } \\
\text { politics }\end{array}$ & $\begin{array}{c}\text { Stakeholders } \\
\text { influence }\end{array}$ & Politics of identity \\
\hline Biosocial projects performance & Pearson Correlation & .113 & $.331^{* *}$ & $.311^{* *}$ \\
in informal settlements & Sig. (2-tailed) & .278 & .001 & .002 \\
**. Correlation is significant at the 0.01 level (2-tailed). & & 104 & 94 \\
*. Correlation is significant at the 0.05 level (2-tailed). & & & \\
\hline
\end{tabular}

Results on Table 8 above show that organizational politics does not have a significant correlation with performance, since its p-value 0.278 is greater than both 0.05 and 0.01 . Stakeholders influence and Politics of identity had a positive significant correlation with biosocial projects performance in informal settlements nonetheless the correlation was moderate for both cases. 


\subsection{Inferential Analysis of Influence of Political Environment on Biosocial Projects Performance in Informal Settlements in Nairobi County Kenya}

In order to establish causality between the independent variable and the dependent variable a regression model was run using the Ordinary Least Square method. The regression was conducted to determine whether there is a statistical relationship between the indicators of each dependent variable and biosocial projects performance in informal settlements. The analysis of this relationship coincides with testing of the hypothesis.

The results were discussed as per the study hypothesis as follows:

\subsubsection{Hypothesis 1}

The hypothesis coincided with the objective of this study which was:

To establish the extent to which political environment influence biosocial projects performance in informal settlements in Nairobi County, Kenya.

The null hypothesis was:

$\mathrm{H}_{\mathrm{ol}}$ : There is no significant influence of political environment on biosocial projects performance in informal settlements in Nairobi County. To test this hypothesis a regression model of biosocial projects performance in informal settlements and political environment was run.

To run equation, Ordinary Least Square (OLS) method was used to analyze data and results of regression model as presented in Table 9 and 10. Table 9 presents results of individual elements of political environment while Table 10 presents results of political environment as a composite of the individual elements of political environment.

Table 9. Elements of political environment and biosocial projects performance in informal settlements

\begin{tabular}{|c|c|c|c|c|c|}
\hline \multicolumn{6}{|c|}{ Model Summary } \\
\hline \multirow[t]{3}{*}{ Model } & \multirow[t]{2}{*}{$\mathrm{R}$} & & \multirow[t]{2}{*}{ R square } & \multirow[t]{2}{*}{ Adjusted R Square } & \multirow{2}{*}{$\begin{array}{l}\text { Std. Error of the } \\
\text { Estimate }\end{array}$} \\
\hline & & & & & \\
\hline & $.348^{\mathrm{a}}$ & & .121 & .088 & 10.437 \\
\hline \multicolumn{6}{|c|}{ a. Predictors: (Constant) OP, SI, PI } \\
\hline \multicolumn{6}{|c|}{ ANOVA } \\
\hline Model & Sum of squares & Df & Mean Square & $\mathrm{F}$ & \\
\hline Regression & 1212.343 & 3 & 404.114 & 3.710 & $.015^{\mathrm{b}}$ \\
\hline Residual & 8822.834 & 81 & 108.924 & & \\
\hline Total & 10035.176 & 84 & & & \\
\hline
\end{tabular}

\footnotetext{
a. Dependent Variable: Biosocial projects performance in informal settlements
}

b. Predictors: (Constant) Political environment

\begin{tabular}{|c|c|c|c|c|c|}
\hline \multicolumn{6}{|c|}{ Coefficients } \\
\hline \multirow[t]{3}{*}{ Model } & \multicolumn{2}{|c|}{ Unstandardized Coefficients } & \multirow{2}{*}{\multicolumn{3}{|c|}{$\begin{array}{l}\text { Standardized } \\
\text { Coefficients }\end{array}$}} \\
\hline & & & & & \\
\hline & B & Std. Error & Beta & $\mathrm{T}$ & Sig. \\
\hline Constant & 64.951 & 8.800 & & 7.381 & .000 \\
\hline Organizational politics & .046 & .215 & .023 & .216 & .830 \\
\hline Stakeholders influence & .811 & .447 & .198 & 1.812 & .074 \\
\hline Politics of identity & .261 & .121 & .234 & 2.160 & .034 \\
\hline
\end{tabular}

Results on the elements of political environment above show that politics of identity beta coefficient of 0.261 is statistically significant at $5 \%$ level of significance since the P-value of 0.034 is less than 0.05 . Stakeholders influence is statistically significant at $10 \%$ level of significance since the p-value of 0.074 is less than 0.10 . Organizational politics is not statistically significant at any level of significance since it is more than 0.1 . The $\mathrm{R}$ coefficient of 0.348 showed that there is moderate correlation on the elements of political environment and 
biosocial projects performance in informal settlements. The adjusted $\mathrm{R}$ squared of 0.088 implied the elements of political environment explained $8.88 \%$ of the variation on biosocial projects performance in informal settlements while the other variation is described by other variables not encompassed in the model.

F value of 3.710 is statistically significant at $5 \%$ level of significance since the $p$ value of 0.015 is less than 0.05 . Implication to this is that all the elements together are important explanatory variables for biosocial projects performance in informal settlements. The relationship can lead to a transformation of the regression equation to be of the form:

$$
\mathrm{Y}=64.951+0.046 \mathrm{OP}+0.811 \mathrm{SI}+0.261 \mathrm{PI}
$$

Where: $\mathrm{OP}=$ Organizational politics; $\mathrm{SI}=$ Stakeholders influence; $\mathrm{PI}=$ Politics of identity

$\mathrm{F}$ value was significant an indicator that there was a significant relationship between elements of political environment and biosocial projects performance in informal settlements, nonetheless, to ascertain relationship generally between political environment and biosocial projects performance a composite index of political environment comprising of the elements organizational politics, stakeholders influence and politics of identity was run against biosocial projects performance in informal settlements.

Results of regression are displayed on Table 10 below:

Table 10. Political environment and Biosocial projects performance in informal settlements

\begin{tabular}{|c|c|c|c|c|c|}
\hline \multicolumn{6}{|c|}{ Model Summary } \\
\hline \multirow[t]{2}{*}{ Model } & \multirow[t]{2}{*}{$\mathrm{R}$} & \multirow{2}{*}{\multicolumn{2}{|c|}{ R square }} & \multirow[t]{2}{*}{ Adjusted R Square } & \multirow{2}{*}{$\begin{array}{l}\text { Std. Error of the } \\
\text { Estimate }\end{array}$} \\
\hline & & & & & \\
\hline & \multicolumn{2}{|l|}{$.313^{\mathrm{a}}$} & .098 & .087 & 10.445 \\
\hline \multicolumn{6}{|c|}{ b. Predictors: (Constant) Political environment } \\
\hline \multicolumn{6}{|c|}{ ANOVA } \\
\hline Model & Sum of squares & Df & Mean Square & F & \\
\hline Regression & 980.489 & 1 & 980.489 & \multirow[t]{3}{*}{8.988} & \multirow[t]{3}{*}{$.004^{b}$} \\
\hline Residual & 9054.687 & 83 & \multirow{2}{*}{109.093} & & \\
\hline Total & 10035.176 & 84 & & & \\
\hline \multirow{2}{*}{\multicolumn{6}{|c|}{$\begin{array}{l}\text { c. Dependent Variable: Biosocial projects performance in informal settlements } \\
\text { d. Predictors: (Constant) Political environment }\end{array}$}} \\
\hline & & & & & \\
\hline \multicolumn{6}{|c|}{ Coefficients } \\
\hline \multirow[t]{3}{*}{ Model } & \multirow{2}{*}{\multicolumn{2}{|c|}{ Unstandardized Coefficients }} & \multirow{2}{*}{\multicolumn{2}{|c|}{$\begin{array}{l}\text { Standardized } \\
\text { Coefficients }\end{array}$}} & \\
\hline & & & & & \\
\hline & $\mathrm{B}$ & Std. Error & Beta & $\mathrm{t}$ & Sig. \\
\hline (Constant) & 65.879 & 8.281 & & 7.956 & .000 \\
\hline Political environment & .262 & .087 & .313 & 2.998 & .004 \\
\hline
\end{tabular}

Beta coefficient of 0.262 for political environment was statistically significant at $1 \%$ level of significance since the $p$ value 0.004 was less than 0.01 . The implication to this was that political environment was a statistically significant explanatory variable to biosocial projects performance in informal settlements. These results implied that we can reject the null hypothesis and resolve that there is a significant relationship between political environment and biosocial projects performance in informal settlements. This finding concurs with the views of Sebedi (2012), who observed that leadership plays an important role in influencing performance of projects. One form of influence as Sebedi denotes is the use of specific leadership behaviors in interactions with workmates and primary project beneficiaries.

Qualitative data generated through interviews conducted with the key informants on how local leaders influence the day to day running of PLWD projects postulated that local leaders were observed to highly influence 
performance of projects in the informal settlements. They were observed to affect performance through misappropriation of funds and thus affecting budgets. This was mainly blamed to the selfish interests, where the leaders prioritized their needs first before the PLWD. Some of the sentiments were:

"Political leaders have their own social interest which may thus bring conflict of interest when addressing problems of PLWD" "Political leaders highly influence budgeting of resources, which may hinder performance of some projects"

"Political leaders have funds which can help PLWD but they take advantage of their in-capabilities and thus do not assist them"

Apart from political leaders, church leaders were observed to play a minimal role in supporting PLWD. One of the respondent's views was: "Most local leaders like the religious ones fail to recognize the existence of PLWD in their communities making it hard for those running these projects to identify and help them"

\section{Conclusion and Recommendations}

The findings were mainly based on the F statistic which helps to determine if there is a significant relationship between the response variable and the predictive variable. The F statistic was judged based on the p-value. In the event the $\mathrm{p}$ value was less than 0.05 , it was an implication that the $\mathrm{F}$ statistic was statistically significant a further implication that the independent variable statistically explained the dependent variable.

From the objective of this study as per the aforementioned the null hypothesis tested was; there is no significant influence of political environment and biosocial projects performance in informal settlements in Nairobi county. Results were $\mathrm{F}=8.988, \mathrm{P}=0.004<0.05, \mathrm{r}=0.313, \mathrm{R}^{2}=0.087$. The correlation coefficient 0.313 was moderately low though positive. F statistic however was statistically significant an implication that the null hypothesis is rejected and we conclude that there is a significant relationship between political environment and biosocial projects performance in informal settlements in Nairobi County.

The study further points out that there is a need for accountability of people in higher positions on service delivery. Particularly having leaders or project managers who are transparent during implementation of biosocial projects. This will have an effect on increase of job opportunities to people living with disabilities. In order to sustain it a need to increase in numbers of centers that care for people living with disabilities is also recommended and in addition terms of business opportunities and representation given to people living with disabilities should be fair, equal and without bias. Finally, the study recommends continued advocacy on maters touching people with disabilities and also on communities' participation and development of their capacity on improving their role on meaningful projects interventions. Initiation of awareness programs so that people living with disabilities can know their rights, hence easy for them to be involved in decision-making of projects that target them.

\subsection{Summary of the Test Hypothesis}

Table 11 presents summary of test hypothesis and results

Table 11. Summary of tests of hypothesis and results

\begin{tabular}{l|l|l|l|l}
\hline Research Objective & Hypotheses & Results & Table & Remarks \\
\hline $\begin{array}{l}\text { To establish the } \\
\text { extent to which }\end{array}$ & $\begin{array}{l}\text { Ho: There is no } \\
\text { significant influence } \\
\text { political environment }\end{array}$ & $\mathrm{F}=8.988$ & Table 4.36 \\
influence biosocial & $\begin{array}{l}\text { environment on } \\
\text { projects performance }\end{array}$ & $\begin{array}{l}\text { biosocial projects } \\
\text { informal } \\
\text { performance in } \\
\text { informal settlements } \\
\text { in Nairobi County. }\end{array}$ & $\mathrm{r}=0.313$ & $\mathrm{R}^{2}=0.087$. \\
settlements the null \\
Nairobi County, \\
Kenya.
\end{tabular}

The objective of the study was to establish the extent to which political environment influence biosocial projects performance in informal settlements in Nairobi County, Kenya. Political environment was defined in terms of organizational politics, stakeholders influence and politics of identity. In terms of ranking, the highest was 
organizational politics, followed by stakeholder's influence and finally politics of identity. In running the regression model, the most significant variables were politics of identity and stakeholders influence. Generally, however as a composite of all these variables, political environment was observed to be an important explanatory variable for performance of projects directing to rejection of the null hypothesis.

\section{References}

Ahlemann, F., El Arbi, F., Kaiser, M. G., \& Heck, A. (2012). A process framework for theoretically grounded prescriptive research in the project management field. International Journal of Project Management, 3(1), 456. https://doi.org/10.1016/j.ijproman.2012.03.008

Alan, B., \& Emma, B. (2007). Business Research Methods (2nd ed.). Oxford University Press.

Creswell, J. W. (2012). Educational research: Planning, conducting, and evaluating Quantitative and qualitative research. Upper Saddle River, NJ: Prentice Hall.

DiMaggio, P. J., Powell, W. W. (1991). The New Institutionalism and Organizational Analysis. Chicago, IL: University of Chicago Press.

Frauke, K., Stanley, P., \& Roger, T. (2008). Social Desirability Bias in CATI, IVR, and Web Surveys: The Effects of Mode and Question Sensitivity. Public Opinion Quarterly, 72(5), 847-865. https://doi.org/10.1093/poq/nfn063

Gakuu, K., \& Keiyoro. (2016). Fundamentals of Research methods: Concepts, Practiv and Application. Kenya Aura Publishers.

Government of Kenya. (2012). Press release. Government printer.

Hernandez-Plaza, S., Garcı'a-Ramı'rez, M., Camacho, C., \& Paloma. (2010). Mobility and wellbeing. In C. Stuart (Ed.), The psychology of global mobility. International Psychology. New York: Springer.

Johnson, R. B., \& Anthony, J. O. (2004). Mixed Methods Research: A Research Paradigm Whose Time Has Come. https://doi.org/10.3102/0013189X033007014

Kenya National Disability survey 2008 report.

Kenya National Survey for Persons with Disabilities. (2008). Preliminary report available. Retrieved from www.afri-can.org

Kidombo, G., \& Keiyoro. (2013). Fundamentals of Management: Theories, concepts and Practices. Kenya Aura Publishers.

Lantz, B. (2013). Equidistance of Likert-Type Scales and Validation of Inferential Methods Using Experiments and Simulations. The Electronic Journal of Business Research Methods, 11(1), 16-28.

Mabin, V. J., \& Balderstone, S. J. (2003). The performance of the theory of constraints methodology: Analysis and discussion of successful TOC applications. International Journal of Operations \& Production Management, 23(6), 568-595. https://doi.org/10.1108/01443570310476636

Moriya, N. (2008). Noise-Related Multivariate Optimal Joint-Analysis in Longitudinal Stochastic Processes in Progress in applied mathematical modeling." In Fengshan Yang. Progress in 224 Applied Mathematical Modeling. Nova Science Publishers, Inc.

Mugenda, M. O. (2008). Research Methods: Qualitative and Quantitative. Nairobi Acts Press.

Nairobi County Integrated Development plan, NCIDP 2013-2014.

Nairobi Cross-sectional Slums Survey (NCSS). (2012). Population and Health Dynamics in Nairobi's Informal Settlements, Nairobi, Kenya.

Orlikowski, W. (1994). Improvising organizational transformation over time: a situated change Perspective. Inform Syst Res., 7, 63-92. https://doi.org/10.1287/isre.7.1.63

Saunders, M., Lewis, P., \& Thornhill A. (2003). Research Methods for Business Students (3rd ed.). Prentice Hall Publishers.

Scott, W. R. (1995). Institutions and Organizations. Thousand Oaks, CA: Sage.

Shapiro, S. S., \& Wilk, M. B. (1965). An analysis of variance test for normality (complete samples). Bimetrika, 52(3-4), 591-611. https://doi.org/10.1093/biomet/52.3-4.591

Shield, P., \& Rangarjan, N. (2013). A Playbook for Research Methods: Integrating Conceptual Frameworks and 
Project Management. Stillwater, OK: New Forums Press.

World Bank. (2003). Adolescents and Youth with Disability: Issues and Challenges. International Policy and

Program Review with Recommendations. Washington, DC: World Bank. Retrieved from http://siteresources.worldbank.org/EXTLACREGTOPHIVAIDS/Resources/Adolescents

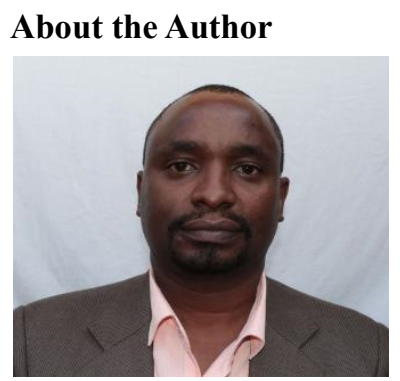

Dr. Ngacha Njeri, PhD, OFS is a Part time Lecturer at the University of Nairobi in the Department of Open Distance and e-Learning. He is by Profession a Monitoring and Evaluation Specialist with Vast experience in Qualitative Research using NVIVO software and Quantitative Researcher using SPSS.

\section{Contacts: snnjeri@gmail.com}

Cell Phone: +254720393738

\section{Copyrights}

Copyright for this article is retained by the author(s), with first publication rights granted to the journal.

This is an open-access article distributed under the terms and conditions of the Creative Commons Attribution license (http://creativecommons.org/licenses/by/4.0/). 